\title{
Antibody-Drug Conjugates for Cancer Therapy
}

\author{
Adam C. Parslow 1,2, Sagun Parakh 1,2,3, Fook-Thean Lee ${ }^{1}$, Hui K. Gan 1,2,3,4 \\ and Andrew M. Scott 1,3,4,5,*
}

1 Tumour Targeting Laboratory, Olivia Newton-John Cancer Research Institute, Heidelberg, Victoria 3084, Australia; adam.parslow@onjcri.org.au (A.C.P.); sagun.parakh@onjcri.org.au (S.P.);

ft.lee@onjcri.org.au (F.-T.L.); hui.gan@onjcri.org.au (H.K.G.)

2 School of Cancer Medicine, La Trobe University, Heidelberg, Victoria 3084, Australia

3 Department of Medical Oncology, Olivia Newton-John Cancer and Wellness Centre, Austin Health, Heidelberg, Victoria 3084, Australia

4 Department of Medicine, University of Melbourne, Melbourne 3010, Australia

5 Department of Molecular Imaging and Therapy, Austin Health, Heidelberg, Victoria 3084, Australia

* Correspondence: andrew.scott@onjcri.org.au; Tel.: +61-3-9496-5876

Academic Editor: Michael A. Firer

Received: 10 May 2016; Accepted: 27 June 2016; Published: 11 July 2016

\begin{abstract}
Antibody-drug conjugates (ADCs) take advantage of the specificity of a monoclonal antibody to deliver a linked cytotoxic agent directly into a tumour cell. The development of these compounds provides exciting opportunities for improvements in patient care. Here, we review the key issues impacting on the clinical success of ADCs in cancer therapy. Like many other developing therapeutic classes, there remain challenges in the design and optimisation of these compounds. As the clinical applications for ADCs continue to expand, key strategies to improve patient outcomes include better patient selection for treatment and the identification of mechanisms of therapy resistance.
\end{abstract}

Keywords: ADC; antibody-drug conjugate; resistance; monoclonal antibodies; cancer; immunotherapy

\section{Introduction}

The search for the "magic bullet" to selectively deliver a cytotoxic agent to the site of a cancerous cell has been the goal of clinical oncology for more than 100 years [1]. Monoclonal antibody (mAb) therapy is arguably one of the most successful treatment strategies for patients with haematological and solid tumour malignancies [2]. Antibody-based therapies have therapeutic effects through a range of mechanisms, including altering antigen or receptor function and signalling, inducing complement-dependent cytotoxicity (CDC) or antibody-dependent cytotoxicity (ADCC) [3]. Even with more than 20 monoclonal antibodies approved for therapeutic use in cancer patients, further development is required to increase their effectiveness and reduce their toxicity [4]. Antibody-drug conjugates combine the ability to link a cytotoxic payload to a monoclonal antibody which specifically recognises a cellular surface antigen and deliver a toxic payload directly into the target cell [5]. The development of an effective ADC therapy is influenced by the interplay of the three main structure elements of the molecule: the antibody, the linker, and the covalently attached cytotoxic agent [6]. Depending of the target antigen in question, the use of monoclonal antibodies reduces the off target effects by limiting the exposure of normal tissues to the payload compared with conventional systemic therapies [2]. The ability to uniquely deliver a cytotoxic payload to a tumour cell provides a tenable excitement to the cancer biology field.

This review will provide a summary of the key factors leading to the emerging clinical success of ADCs and identify the challenges and advancements that have defined this exciting area of cancer therapy. 


\section{Selecting an Appropriate Target}

The appropriate selection of the antigen-binding site is a critical developmental step for the eventual success of an antibody-drug conjugate. As such, the most effective antigens share certain characteristics. The monoclonal antibody selected, as the basic structural element of the ADC, binds to a target antigen present on the surface of the cell that is accessible via the bloodstream. Following binding, the complex must be rapidly internalised, allowing the release the cytotoxic agent within the tumour cell (Figure 1) [7,8]. Ideally, the antigen should be well-characterised, proportionally abundant, and accessible on tumour cells compared to surrounding normal cell populations $[9,10]$. This is to allow the preferential binding and delivery of the ADC to malignant populations, reducing the potential for toxicity to normal cells. The antibody selected should have a high affinity for its target, increasing the potential for internalisation of the cytotoxic agent. Heterogeneity throughout the tumour population should be avoided, and antigens that shed and are abundant in the circulation should be avoided. The uptake of the ADC is limited by the rate of this target antigen-ADC complex internalisation [11]. The rapid uptake of the ADC also reduces extracellular payload release. The ability to identify an appropriate antigen target that contains all these characteristics is, in practice, difficult. The selection of antigen in further complicated by the constant evolutionary pressure placed on cancer cell populations during treatment. Ideally, the target antigen should not be downregulated post-treatment to maintain cellular sensitivity to the therapy.

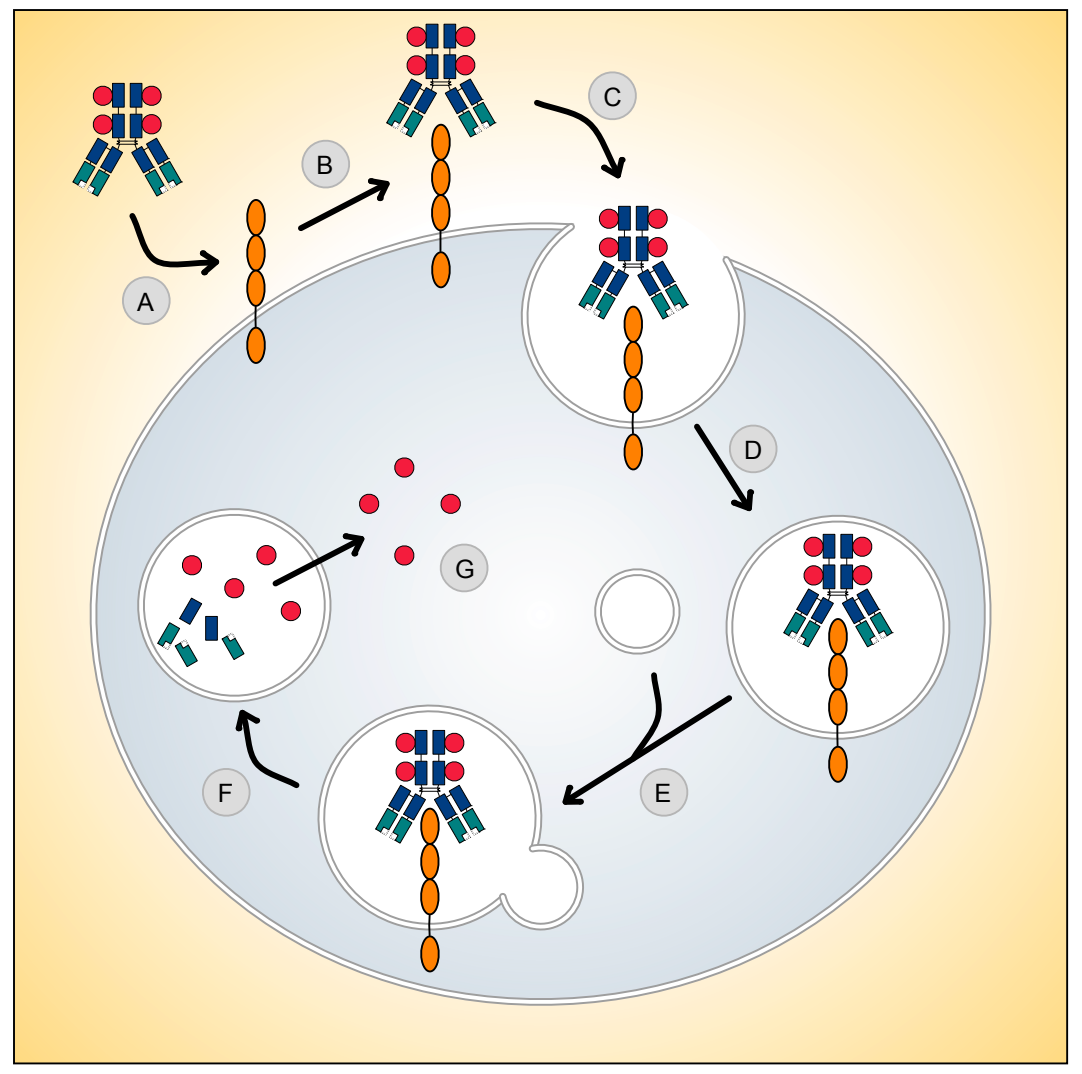

Figure 1. Mechanism of antibody-drug conjugate (ADC) action. (A) An ideal antigen target for ADC therapy is accessible via the circulation. (B) Following antigen binding, (C) the antigen-ADC complex is rapidly internalised into (D) endosomal vesicles and is processed along the (E) endosomal-lysosomal pathway. (F) In this acidic and proteolytic rich environment, degradation occurs, $(\mathbf{G})$ resulting in the intracellular release of cytotoxic compound. 


\section{Antibody-Drug Conjugation}

The chemical conjugation of the antibody and the cytotoxic payload has a major influence on the pharmacokinetics, selectivity, and the therapeutic index of ADC-based therapies [12]. A linker is the required covalent connection between the cytotoxic compound and the antibody. The linker influences the stability and drug to antibody ratio (DAR) of the therapeutic agent. These parameters are critical for the overall success of an ADC-based design. With the high potency of the payloads chosen, linkers must be stable within the bloodstream to limit early payload release and allow tumour site targeting to occur. However, this stability must be context-dependent: once inside the cell, these linkers must be efficient in releasing the payload to induced the cytotoxic effect [13].

Conventional ADC conjugation involves methods of alkylation of reduced interchain disulphides and alkylation or acylation of lysine residues [9]. These conjugation methods generate heterogeneous mixtures of ADCs with variable drug per antibody ratios (DARs). This varies between zero and eight conjugated payloads per antibody [14]. T-DM1, for example, has on average a DAR of 3.5 [15]. The position and number of payloads bound to the antibody can have profound effects on the binding to the antigen, the aggregation of the ADC, the pharmacokinetic characteristics of the antibody construct, and even the safety profile of the ADC [16].

Improving the antibody site for linker conjugation has been greatly enhanced through advancements in protein engineering. Antibody site-specific alterations enhance linker conjugation and result in homogeneous ADCs. These alterations can be mediated through enzymatic conjugation or insertion of reactive cysteine or chemoselective functional groups of unnatural amino acid residues into the antibody protein sequence [17]. The covalent connection between drug and antibody has been traditionally mediated through the thiol group of cysteine or the epsilon amino group of lysine residues [18].

The majority of ADCs in clinical trials attach the linker to a cysteine of the antibody. Cysteines are present within the intra and interchain disulphide bridges within an antibody. The presence of 4 interchain disulphide bridges within in an IgG1 antibody typically results in only eight possible conjugation sites. This reduces potential ADC heterogeneity resulting from these reactions. The linking to antibody-derived cysteine is commonly mediated through maleimide-type linkers. The two most common are maleimidocaproyl (mc) and maleimidomethyl cyclohexane-1-carboxylate (mcc). An example is the vc-MMAE linker-payload, which contains a mc spacer attached to the valine-citrulline (vc) dipeptide, which in turn is linked to the self-immolative spacer, para-amino benzyloxycarbonyl (PABC), which is attached to a monomethylauristatin E (MMAE) payload (mc-vc-PABC-MMAE). The mc spacer allows for the lysosomal vc processing via cathepsin B, liberating an unstable PABC-MMAE product, from which PABC disintegrates leaving a chemically unmodified MMAE [19]. There are four lysine-based linkers currently used for ADCs in the clinic: $\mathrm{N}$-succinimidyl-4-(2-pyridyldithio) butanoate (SPDB), N-succinimidyl-4-(2-pyridyldithio)-2-sulfo butanoate (sulfo-SPDB), maleimidomethyl cyclohexane-1-carboxylate (MCC), and hydrazone [20]. In comparison to the limited number of cysteines, an IgG1 contains approximately 90 lysines, 30 of which are available for conjugation. This is advantageous, as no antibody structural changes are required, but they increase the potential for ADC heterogeneity during production.

Linker chemistry can be broadly defined into two groups: either cleavable or non-cleavable linkers. Cleavable linkers can be sub-characterised as either: acid-sensitive, protease-sensitive, or glutathione-sensitive. A cleavable linker takes advantage of the intracellular environment of target cells. Acid-liable linkers, such as hydrazone, require the low $\mathrm{pH}$ of endosomes and lysosomes to trigger its hydrolysis and release of toxic payload. One such example, hydrazone, was used as the linker for gematuzumab ozogamicin, an ADC combining an anti-CD33 antibody to a calicheamicin-derived cytotoxic. However, a low serum plasma stability of approximately $48-72 \mathrm{~h}$ was observed [21].

Peptide linkers of the protease sensitive class are more stable than an acid-sensitive-based linker and has been successfully used in the clinically approved brentuximab vedotin linking the payload monomethylauristatin E (MMAE) to the anti-CD30 antibody [19]. Peptide linkers, such as the 
valine-citrulline (vc) dipeptide, contain an engineered lysosomal-specific protease (i.e., cathepsin B) cleavage site, allowing for the chemically unmodified release of cytotoxic payload from the lysosome compartment. Taking advantage of the increased glutathione concentration within tumour cells, the reducible, disulphide bond-based glutathione sensitive linkers are a third major sub-category of cleavable linkers [9,22]. However, low levels of glutathione is also present within the circulation $(2.8 \pm 0.9 \mu \mathrm{M})$ [23]. Increasing levels of disulphide steric hindrance through the insertion of methyl groups has proportionally reduced their untimely release within the circulation [24]. Lorvotuzumab mertansine (IMGN901) is the most clinically advanced ADC employing a hindered disulphide linker. This anti-CD56 targeting ADC with a maytanisinoid (DM1) payload has shown efficacy against Merkel cell carcinoma in early phase trials and has been granted orphan status by the U.S. Food and Drug Administration (FDA) [25].

The second class of ADC linking strategies involves the use of non-cleavable thioether linkers that require the post-internalisation degradation of the ADC complex within the lysosomal and endosomal compartments. This disintegration results in the release of a cytotoxic agent still attached with the linker and an amino acid from the original antibody attachment site [26]. Ado-trastuzumab emtansine (T-DM1) has successfully used a non-cleavable linker to combine a maytansinoids toxic to the anti-HER2 trastuzumab antibody [27]. Non-cleavable linkers have improved stability in the bloodstream, longer half-lives, and hence reduced risk of off-target toxicity [28]. T-DM1, for example, has a serum stability of more than three days [29]. The success of each linking strategy is context-dependent, with advantages and disadvantages for each. The conjugation method used to combine the linker to exposed residues on the surface of antibody is another pivotal step in the manufacture of a successful ADC.

\section{Antibody-Drug Conjugate Payloads}

The first generation of ADC payloads were developed around clinically approved cytotoxic agents. The well-known safety and efficacy of agents such as doxorubicin, 5-fluorouracil, and methotrexate was seen as advantageous; however, these agents did not achieve clinical benefit as ADCs due to their moderate cytotoxic potential, lack of selectivity, and low intracellular drug concentration [11]. Subsequent approaches have involved identifying drugs that were suitable for antibody conjugation and would deliver an effective cytotoxic dose, even with small efficiencies in intracellular delivery. The two most commonly used cytotoxic payloads focus on either the tubulin-targeting anti-mitotic agents or DNA-damaging drugs. The majority of payloads in current clinical development reside in the broad class of tubulin-targeting anti-mitotic agents, the maytansinoids and auristatins. These agents inhibit spindle and microtubule dynamics during interphase, resulting in G2/M mitotic arrest [30,31]. Payloads that target the microtubule network may not be limited to inhibiting cellular division and may also inhibit intracellular trafficking of proteins essential for cancer cell function [32,33]. This is particularly important for ADC-based targeting of tumour initiating cells (TIC) or quiescent cell populations.

The search for the next generation of cytotoxic payloads continues, with one approach being the development of DNA-damaging agents such as pyrrolobenzodiazepine (PBD). PBD dimers covalently bind to the minor groove of DNA and display promising pre-clinical results including efficacy 10 times lower than anti-microtubule alternatives [34,35]. The HER2-targeting ADC, SYD985, has shown promising results in early Phase I trials, with a new payload class of DNA-alkylating duocarmycins. This cleavable linker-duocarmycin payload, valine-citrulline-seco Duocarmycin hydroxybenzamide azaindole (vc-seco-DUBA), is rapidly degraded in the plasma, potentially increasing the maximum tolerated doses for this ADC class [36,37]. Potent anthracycline analogues are also showing important cytotoxicity for in vivo models conditionally resistant to MMAE-based ADCs [38]. Other agents under investigation include the RNA polymerase II binding $\alpha$-amanitin [39] which can induce inhibition of DNA transcription and apoptosis; as well as the tubulin polymerisation inhibiting tubulysins [40]. 
In addition to the direct killing of cells that are target antigen positive, some ADCs are also able to kill target antigen negative neighbouring cell populations, known as a bystander killing effect [41]. The effective clinical response of the anti-CD30 MMAE delivering brentuximab vedotin is suggested to be partially induced by the diffusion of MMAE into the surrounding tumour environment [42]. The 3\% CD30-positive target expression in lymphoma cells in a highly responsive brentuximab vedotin patient is highly suggestive of this hypothesis [43]. The membrane permeable PBD and MMAE payloads are able to induce potent bystander killing mechanisms compared with the more hydrophilic and thus less permeable MMAF molecule, which has reduced bystander killing potential [26]. The differing dynamics of bystander killing between payloads can be used to overcome reduced amounts of target antigen expression to induce tumour response. With increased tumour heterogeneity observed especially in solid tumours, effective cell kill can be induced via bystander mechanisms through potent membrane permeable ADC payloads in low target antigen environments.

The importance of payload selection for stem cell targeting was recently reported in the analysis of two ADCs targeting the Lgr5+ colorectal stem cell and putative cancer stem cell marker [44]. An anti-microtubule targeting anti-LGR5-vc-MMAE ADC was effective in vivo, without affecting the homeostasis of the normal intestinal epithelium in the mouse models explored. In comparison, the DNA damaging anti-LGR5-NMS818 ADC resulted in target antigen-based toxicity that affected the normal intestinal epithelium. Free NMS818 is known to be 1-100 times more potent than free MMAE, increasing the potential for bystander toxicity in Lgr5- non-targeted neighbouring cell populations. This intestinal model exemplifies the important considerations required for the selection of appropriate drug conjugate payloads based on the mechanism of action and the availability of free payload within the tumour type of interest.

\section{Clinically Approved Antibody-Drug Conjugates}

The US Food and Drug Administration (FDA) has approved several ADCs for clinical use in haematological malignancies and some solid tumour types. Many more ADCs are in late stage clinical development and have shown promising initial results (Table 1). The first ADC to gain FDA approval (in 2000) was gemtuzumab ozogamicin (Mylotarg®) for patients over the age of 60 who suffered their first relapse of CD33 positive acute myeloid leukaemia (AML) and were ineligible for chemotherapy [45]. This ADC comprised a humanised IgG4 CD33 antibody coupled with a DNA-binding calicheamicin derivitive. Although this agent sparked renewed clinical interest in the development and design of the ADC as a therapeutic class, this particular agent was voluntarily withdrawn by its manufacture following the post-approval Phase III study, which failed to identify an improved survival within the chemotherapy and gemtuzumab ozogamicin combinational groups when compared to chemotherapy alone with previously untreated AML [46]. Given the heterogeneous nature of AML, it is still believed that a subpopulation of AML patients would benefit from the addition of a gemtuzumab ozogamicin regime. More recent randomised studies have displayed statistically significant overall survival with gemtuzumab ozogamicin with or without chemotherapy [47-50]. The reason for this discrepancy still remains unclear, but it could in part be due to the lower doses of daunorubicin used in most of these trials or the fractionation of gemtuzumab ozogamicin treatment, which appeared to be better tolerated, allowing for a greater overall dose to be administered. These studies have reignited the clinical debate regarding the clinical use of gemtuzumab ozogamicin [51,52]. 
Table 1. Selected antibody-drug conjugates in clinical development.

\begin{tabular}{|c|c|c|c|c|c|}
\hline Payload & $\begin{array}{l}\text { Target } \\
\text { Antigen }\end{array}$ & $\begin{array}{l}\text { Antibody-Drug } \\
\text { Conjugate }\end{array}$ & Lead Indication & Phase & Reference \\
\hline \multirow[t]{6}{*}{ Calicheamicin } & CD22 & Inotuzumab & B-cell malignancy & FDA & [53] \\
\hline & & Ozogamicin & & Breakthrough & \\
\hline & & & & Therapy & \\
\hline & & & & Designation & \\
\hline & CD33 & Gemtuzumab & AML & FDA approved & [46] \\
\hline & & Ozogamicin (GO) & & but withdrawn & \\
\hline \multirow[t]{6}{*}{ DM1 } & CD22 & Brentuximab & Hodgkin's & FDA approved & [54] \\
\hline & & Vedotin & $\begin{array}{l}\text { Lymphoma, } \\
\text { Systemic ALCL }\end{array}$ & & \\
\hline & CD56 & $\begin{array}{l}\text { Lorvotuzumab } \\
\text { mertansine }\end{array}$ & Multiple myeloma & $\mathrm{I} / \mathrm{II}$ & [55] \\
\hline & CD138 & BT062 & Multiple myeloma & $\mathrm{I} / \mathrm{IIa}$ & [56] \\
\hline & HER2 & $\begin{array}{l}\text { Trastuzumab } \\
\text { emtansine (T-DM1) }\end{array}$ & Breast cancer & FDA approved & [57] \\
\hline & MUC1 & SAR-566658 & Solid tumours & $\mathrm{I} / \mathrm{II}$ & [58] \\
\hline \multirow[t]{3}{*}{ DM4 } & CD22 & $\begin{array}{l}\text { Pinatuzumab } \\
\text { vedotin }+ \\
\text { Rituximab }\end{array}$ & DLBCL, FL & II & [59] \\
\hline & CD79b & $\begin{array}{l}\text { Polatuzumab } \\
\text { vedotin }+ \\
\text { Rituximab }\end{array}$ & DLBCL, FL & II & [59] \\
\hline & GPNMB & $\begin{array}{l}\text { Glembatumumab } \\
\text { vedotin }\end{array}$ & Melanoma & II & [60] \\
\hline MMAE & PSMA & PSMA ADC & Prostate cancer & II & [61] \\
\hline MMAF & EGFR & ABT-414 & GBM & $\mathrm{IIb} / \mathrm{III}$ & NCT02573324 [62] \\
\hline \multirow[t]{2}{*}{ SN-38 } & CEACAM & IMMU-130 & Colorectal cancer & II & NCT01915472 \\
\hline & Trop2 & IMMU-132 & Epithelial cancers & $\mathrm{I} / \mathrm{II}$ & {$[63]$} \\
\hline $\begin{array}{l}\text { Liposomal } \\
\text { doxorubicin }\end{array}$ & HER2 & MM-302 & $\begin{array}{l}\text { HER2 positive } \\
\text { metastatic breast } \\
\text { cancer }\end{array}$ & II & NCT02213744 \\
\hline
\end{tabular}

In 2011, following an accelerated process, brentuximab vedotin (Adcetris ${ }^{\circledR}$ ), received FDA approval for the treatment of patients with Hodgkin lymphoma (HL) after failure of autologous stem cell transplantation (ASCT) or after failure of at least two prior multiagent chemotherapy regimens in patients who are not ASCT candidates. This approval also included treatment for patients with systemic anaplastic large-cell lymphoma (sALCL) after failure of at least one prior multiagent chemotherapy regime [64]. Brentuximab vedotin is comprised of an anti-CD30 chimeric antibody attached to monomethyl auristatin E (MMAE) via a protease-cleavable dipeptide linker [5]. This approval was based on the pivotal Phase II study of 102 patients with an overall objective response rate (ORR) of $75 \%$ with complete remission (CR) in $34 \%$ of patients. The median duration of response for those patients in CR was 20.5 months; however, showing the veracity of this disease, the median progression-free survival time for all patients on the trial was only 5.6 months [54]. More recently, brentuximab vedotin received additional FDA approval for patents with unfavourable-risk relapsed or primary refractory classic Hodgkin's lymphoma who have undergone autologous stem-cell transplantation. The AETHERA Phase III trial noted an impressive median progression-free survival (PFS) improvement of 42.9 months in the brentuximab vedotin group compared with 24.1 months in the placebo treated group [65].

The first ADC to receive FDA approval in solid tumours was ado-trastuzumab emtansine (T-DM1, Kadcyla $^{\mathrm{TM}}$ ). T-DM1 was approved for use as a single agent for the treatment of patients with human epidermal growth factor receptor 2 (HER2) positive metastatic breast cancer (MBC) who previously received trastuzumab and a taxane, separately or in combination [66]. T-DM1 is an antibody-drug 
conjugate comprised of the humanised anti-HER2 antibody trastuzumab (Herceptin®) conjugated to the anti-microtubule cytotoxic, maytnsinoid DM1 via a non-cleavable thioether linker [67]. After the in vitro anti-tumour activity of ado-trastuzumab emtansine in trastuzumab-sensitive and resistant cells lines was demonstrated, as well as efficacy in pre-clinical trastuzumab and lapatinib cross-resistant breast cancer xenograft models $[67,68]$, T-DM1 was well tolerated and showed early signs of efficacy in early phase clinical trials [15,69-71]. In the Phase II (TDM4374g) trial, 110 HER2 positive advanced breast cancer patients were compared [72]. These patients had received on average seven therapeutics prior to being selected on the trial, including the HER2 targeted trastuzumab and lapatinib, alongside capecitabine as well as a taxane and an anthracycline [73]. The overall response rate in this patient population was $34.5 \%$, with clinical benefit seen in $48.2 \%$ of patients. The key finding from this study was that, even in patient populations that were refractory to trastuzumab and taxanes, a large portion retained HER2 expression and were responsive to a trastuzumab-based ADC. FDA approval for T-DM1 was granted after the successful 991 patient Phase III EMILIA trial in which a progression-free survival overall of 9.6 months with T-DMI versus 6.4 months with lapatinib plus capecitabine was observed [57].

Research into novel ADCs has considerable momentum, with over 100 open clinical trials (clinicaltrials.gov) currently exploring ADCs against novel antigen targets in cancer patients. Although the focus of ADCs has remained in the treatment of haematological malignancies, the success of T-DM1 in solid tumours gives confidence to the clinical development of other novel constructs. A number of ADCs directed against solid tumours are showing promising early results (Table 2).

Table 2. Selected novel antibody-drug conjugates in early development.

\begin{tabular}{|c|c|c|c|c|}
\hline Payload & Target Antigen & $\begin{array}{l}\text { Antibody-Drug } \\
\text { Conjugate }\end{array}$ & Lead Indication & Phase \\
\hline \multirow{2}{*}{$\begin{array}{l}\text { Auristatin } \\
\text { microtubule inhibitor }\end{array}$} & PTK7 & PF-06647020 & Solid tumours & Phase I \\
\hline & NOTCH-3 & PF-06650808 & Solid tumours & Preclinical \\
\hline \multirow[t]{7}{*}{ DM1 } & CD70 & AMG-172 & Renal cell carcinoma & Phase I \\
\hline & CD22 & Anti-CD22-MCC-DM1 & $\begin{array}{l}\text { Non-Hodgkin } \\
\text { lymphoma }\end{array}$ & Preclinical \\
\hline & Mesothelin & BAY 94-9343 & $\begin{array}{l}\text { Mesothelioma, } \\
\text { pancreatic, ovarian, } \\
\text { NSCLC }\end{array}$ & Phase I \\
\hline & CD37 & IMGN-529 & NHL & Phase I \\
\hline & Folate receptor 1 & IMGN853 & Ovarian cancer NSCLC & Phase I \\
\hline & CD56 & $\begin{array}{l}\text { Lorvotuzumab } \\
\text { mertansine }\end{array}$ & $\begin{array}{l}\text { SCLC, Merkel cell, } \\
\text { ovarian }\end{array}$ & Phase I \\
\hline & CD19 & SAR-3419 & NHL & Phase I \\
\hline \multirow[t]{2}{*}{ DM4 } & Nectin-4 & ASG-22ME & Solid tumours & Phase I \\
\hline & Carbonic anhydrase & BAY 79-4620 & Solid tumours & Phase I \\
\hline \multirow[t]{7}{*}{ MMAE } & SLC44A4 & ASG-5ME & Pancreatic cancer & Phase I \\
\hline & SLTRK6 & ASG-15ME & Urothelial tumours & Phase I \\
\hline & CD22 & DCDT2980S & $\begin{array}{l}\text { Non-Hodgkin } \\
\text { lymphoma }\end{array}$ & Preclinical \\
\hline & $\begin{array}{l}\text { Sodium-dependent } \\
\text { phosphate transporter }\end{array}$ & DNIB0600A & $\begin{array}{l}\text { NSCLC, Ovarian } \\
\text { cancer }\end{array}$ & Phase I \\
\hline & Axl & HuMax-Axl-ADC & $\begin{array}{l}\text { Solid, haematological } \\
\text { malignancies }\end{array}$ & Preclinical \\
\hline & CD19 & SGN CD19A & NHL & Phase I \\
\hline & CD70 & SGN-75 & $\mathrm{RCC}$ & Phase I \\
\hline \multirow[t]{2}{*}{ MMAF } & ENPP3 & AGS-16M8F & Renal cell carcinoma & Phase I \\
\hline & $5 \mathrm{~T} 4$ & PF 06263507 & Solid tumours & Phase I \\
\hline \multirow[t]{2}{*}{ PBD } & CD19 & ADCT-402 & NHL & Phase I \\
\hline & CD70 & SGN-CD70A & NHL & Preclinical \\
\hline
\end{tabular}




\section{Antibody-Drug Conjugate Toxicities}

ADCs have been shown to be highly efficacious across a broad spectrum of haematological malignancies and solid tumours in preclinical animal models; however, when evaluated in the clinical setting, their therapeutic windows are hampered by toxicities that are often related to the drug component of the ADC [74]. Dose limiting ocular toxicities have been described for ADCs conjugated with MMAF $[75,76]$. Similarly, reversible ocular toxicity in the cornea has been reported for DM4-conjugated antibodies [77-79]. This appears independent of the target antigen, which does not have significant expression in the eye. The toxicity profile of ADCs conjugated with vcMMAE are similar with adverse events that are the most commonly seen, including acute neutropenia and neuropathy [74]. This has been shown with brentuximab vedotin, with peripheral sensory neuropathy the most common cause of treatment discontinuation [80]. As neurons lack CD30 target antigen expression, it is believed that free MMAE results in an inhibition of axonal transport when the microtubule complex is disrupted. In the pivotal Phase II study, the most serious grades 3 and 4 adverse events were neutropenia (20\%), peripheral sensory neuropathy $(8 \%)$, thrombocytopenia $(8 \%)$, and anaemia (6\%) [54]. Other clinically relevant brentuximab vedotin toxicities relate to infusion-related reactions, diarrhoea, and hyperglycaemia [65].

Much interest awaits the publication of the Phase III inotuzumab ozogamicin INO-VATE trial data. In the Phase II investigation of inotuzumab ozogamicin as a single-agent in patients with indolent non-Hodgkin lymphoma (iNHL) who were refractory to rituximab alone, rituximab in combination with chemotherapy, or anti-CD20 radioimmunotherapy, haematological toxicities were the leading cause of treatment discontinuation. Adverse events of grade 3 or greater were associated were primarily thrombocytopenia (56\%) and neutropenia (36\%). Non-haematological toxicities were primarily nausea $(5 \%)$, fatigue $(2 \%)$, and an elevation of aspartate aminotransferase levels $(2 \%)$. In this trial, $58 \%$ of patients reported an adverse event leading to discontinuation of treatment [81].

For the HER2 targeting T-DM1, thrombocytopenia is the dose-limiting toxicity [73]. In the Phase III clinical trials, thrombocytopenia was observed in $4.7 \%$ to $12.9 \%$ of patients. The major side effect of concern for the clinical development of the antibody component of T-DM1, trastuzumab, was the initial observation of cardiotoxicity [82]. This is partially explained though due to the high levels of HER2 expression in cardiac tissue. The T-DM1-induced thrombocytopenia appears to be an off-target toxicity. Recent studies have shown that DM1 effects the differentiation and maturation of megakaryocytes from human haematopoietic stem cells. The DM1-meditated cytotoxic effect is less pronounced on mature megakaryocytes [83].

\section{Recent Antibody-Drug Conjugate Developments}

While ADCs have been shown to have therapeutic activity in a range of cancers, there are opportunities to further enhance therapeutic effects with combination therapy, such as combining ADCs with immunotherapy [84]. The ability of a patient's immune system to co-operate and promote anti-tumour effects has emerged as an important new area of cancer therapy [85]. The induction of tumour cell death following ADC therapy may allow the expression of tumour antigens that, in conjunction with the immune checkpoint blockade, facilitate a host $\mathrm{T}$ cell response against the tumour. A recent preclinical study has shown that brentuximab vedotin is a potent inducer of dendritic cell (DC) maturation [86]. This study identified that, in addition to the cytotoxic capabilities of this ADC, brentuximab vedotin can stimulate a host adaptive immune response in both patient and animal models. When combined with PD-1/PD-L1 inhibition, a strong therapeutic synergy was identified.

These adaptive immune studies have been expanded to studies of T-DM1 [87]. It was observed that, in human primary breast tumours, T-DM1 therapy induced an increase in infiltrating lymphocytes (TILs) as well as increased infiltration of effector $\mathrm{T}$ cells in a murine breast tumour model. T-DM1, as is the case for brentuximab vedotin, promotes the DC maturation leading to $\mathrm{T}$ cell infiltration, while, in combination with anti-PD-1/CTLA-4 therapy, the exhausted T-cell response is 
reinvigorated. This suggests a strong rationale for the combined use of antibody-drug conjugates with immunotherapy-based approaches.

\section{Resistance to Antibody-Drug Conjugate Therapy}

Under a selective therapeutic pressure, a heterogeneous population of tumour cells will provide the opportunity for the development and expansion of treatment resistance sub-populations. The prevalence of treatment resistance is a challenge for ADC drug development, similar to other cancer therapeutics (Figure 2) [2]. The ability to minimise resistance to ADC therapies is being addressed through multiple approaches, including exploration of mechanisms of resistance in both in vitro and in vivo models, and analysis of tumour samples from clinical trials with large scale sequencing and proteomic approaches.

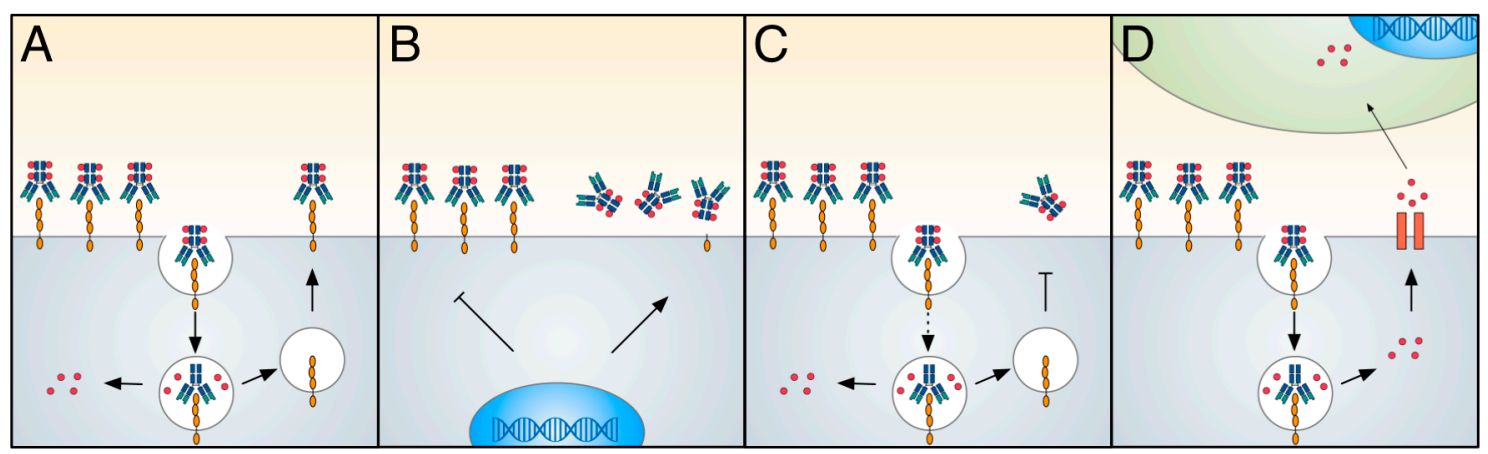

Figure 2. Resistance mechanism for antibody-drug conjugate (ADC) therapies. (A) An effective ADC therapy is dependent on high levels of intracellular cytotoxic payload delivery. Multiple mechanisms have been identified which influence the delivery and retention of cytotoxic payloads. (B) Reduced antigen on the cell surface can result from reduced target gene expression or presence of increased antigen mutations. (C) Reduced cell surface trafficking or recycling will also reduce ADC internalisation. (D) ADC payloads are targets for multidrug resistance (MDR) transporter efflux out of the cell, potentially inducing bystander killing effects (payload-dependent).

The mechanisms of resistance to ADCs are complex, and may be influenced by multiple factors. Primary resistance to ADC based therapy may occur. However, even in initially responding patients as treatment continues, as is the case for T-DM1, acquired resistance inevitably develops [57,71]. A critical factor for T-DM1 success is the intracellular concentration of DM1 [88]. Multiple factors influence the amount of internalised cytotoxin, with patients with higher HER2 expression typically display a better clinical response [27]. If the HER2-T-DM1 complex is not internalised, the DM1 intracellular concentration will not reach the cytotoxic concentration required for cell death. The different rates of ADC internalisation have yet to be analysed across tumour types [89]. Once inside the cell, if the lysosomal degradation pathway is impaired or if the endosomal recycling machinery is overactive, then the T-DM1 will avoid degradation or potentially release free DM1 into the extracellular environment, increasing the chances of off-target effects.

Chronic in vivo exposure to ADCs has generated multiple resistance models of interest. Using continuous exposure to trastuzumab-maytansinoid ADCs (TM-ADC), a TM-ADC resistant breast cancer cell lines 361-TM and JIMT1-TM was developed which allowed for proteomic and transcriptional profiling to be performed [90]. This study identified induction of drug transporter $\mathrm{ABCC} 1$ and reduction of HER2 antigen expression as key nodes of resistance. The proteomic analysis identified alterations in ubiquitylation, potentially affecting the regulation of vesicle and receptor trafficking. Interestingly, the 361-TM resistant cells had increased sensitivity to the HER2-specific kinase inhibitor neratinib and, quite remarkably, were also sensitive to payload delivery via an alternative cleavable linker. Recently reports have explored the potential of PDX models generated from 
a metastatic HER2-positive ductal carcinoma with acquired resistance to T-DM1 to shed light into genomic biomarkers for ADC resistance. Exome profiling identified a loss of heterozygosity of the tumour suppressor TP53 coupled with a point mutation, alongside a non-synonymous mutation in HER2 as potential mechanisms of resistance [91].

In genome-wide association studies of breast cancer cell lines following resistance to antimitotic agents such as paclitaxel and monomethyl-auristatin-E (MMAE), a striking breast cancer subtype sensitivity spectrum to these anti-mitotic agents was observed [92]. Basal-like cell lines were significantly more sensitive to both agents than luminal or HER2-amplified cell lines. After RNA interference analysis, overexpression of the ABCC3 drug transporter was critical for the establishment of in vitro resistance. Multidrug resistance (MDR) involves a family of adenosine triphosphate-binding cassette $(\mathrm{ABC})$ energy-dependent transporters who play critical roles in the efflux of cytotoxic compounds from the cell [93,94]. P-glycoprotein (P-gp, otherwise known as ABCB1 or MDR1) can mediate the efflux of several ADC payloads such as calicheamicin, ausristatins (MMAE) and maytansine (DM1) [5,95]. The substrates for P-gp are hydrophobic and thus advances in the design and selection of appropriate linker technologies can prevent active efflux of the ADC payload out of the cell [96]. As such, increases in cellular retention of the maytansinoid DM1 have been observed through the inclusion of a more hydrophilic maleimidyl-based linker compared to non-polar-based linker counterparts [97]. With recent reports identifying Hodgkin's lymphoma patient samples becoming positive for drug transporters at a time of brentuximab vedotin resistance, further rational ADC linker designs are warranted [98].

\section{Summary}

Antibody-drug conjugates are an exciting treatment strategy for cancer patients. Lessons learned from the development of approved ADCs are informing the selection of novel targets, linkers, payloads, and patient populations most likely to benefit from future ADC-based therapies. With more than 100 clinical trials currently underway, there is great promise for new therapeutic approvals in the future. Importantly, the field must address ways to widen the narrow therapeutic index of ADC-based therapies, which will drive the future development of this class of cancer therapeutics.

Acknowledgments: The authors acknowledge funding support from NHMRC (Fellowship 1084178 and Grants 1087850, 1030469, 1075898 (AMS)), Cancer Australia, Ludwig Cancer Research, John T Reid Trusts, Cure Brain Cancer Foundation, La Trobe University and the Victoria Cancer Agency. Funding from the Operational Infrastructure Support Program provided by the Victorian Government, Australia is also acknowledged.

Author Contributions: All authors were involved in the preparation of the manuscript.

Conflicts of Interest: Hui Gan has research funding from AbbVie Pharmaceuticals, is on an Advisory board for AbbVie and Merck Serono, and has received travel support/honoraria/speaker bureau for Merck Serono, AbbVie, Pfizer, Bayer, Novartis, and Merck. Andrew Scott has research funding support from AbbVie Pharmaceutics and Daiichi-Sankyo Co, is an inventor of mAb806, and has a consultancy and stock ownership of Life Science Pharmaceuticals. The authors have no other relevant affiliations or financial involvement with any organisation or entity with a financial interest in or financial conflict with the subject matter or materials discussed in the manuscript apart from those disclosed.

\section{Abbreviations}

The following abbreviations are used in this manuscript:

$\begin{array}{ll}\text { ABC } & \text { adenosine triphosphate-binding cassette } \\ \text { ADC } & \text { antibody-drug conjugate } \\ \text { ADCC } & \text { antibody-dependent cytotoxicity } \\ \text { ALCL } & \text { anaplastic large-cell lymphoma } \\ \text { ALL } & \text { acute lymphocytic leukaemia } \\ \text { AML } & \text { acute myeloid leukaemia } \\ \text { ASCT } & \text { autologous stem cell transplantation } \\ \text { CDC } & \text { complement-dependent cytotoxicity } \\ \text { CR } & \text { complete response } \\ \text { CTLA-4 } & \text { cytotoxic T lymphocyte-associated protein-4 } \\ \text { DAR } & \text { drug to antibody ratio }\end{array}$




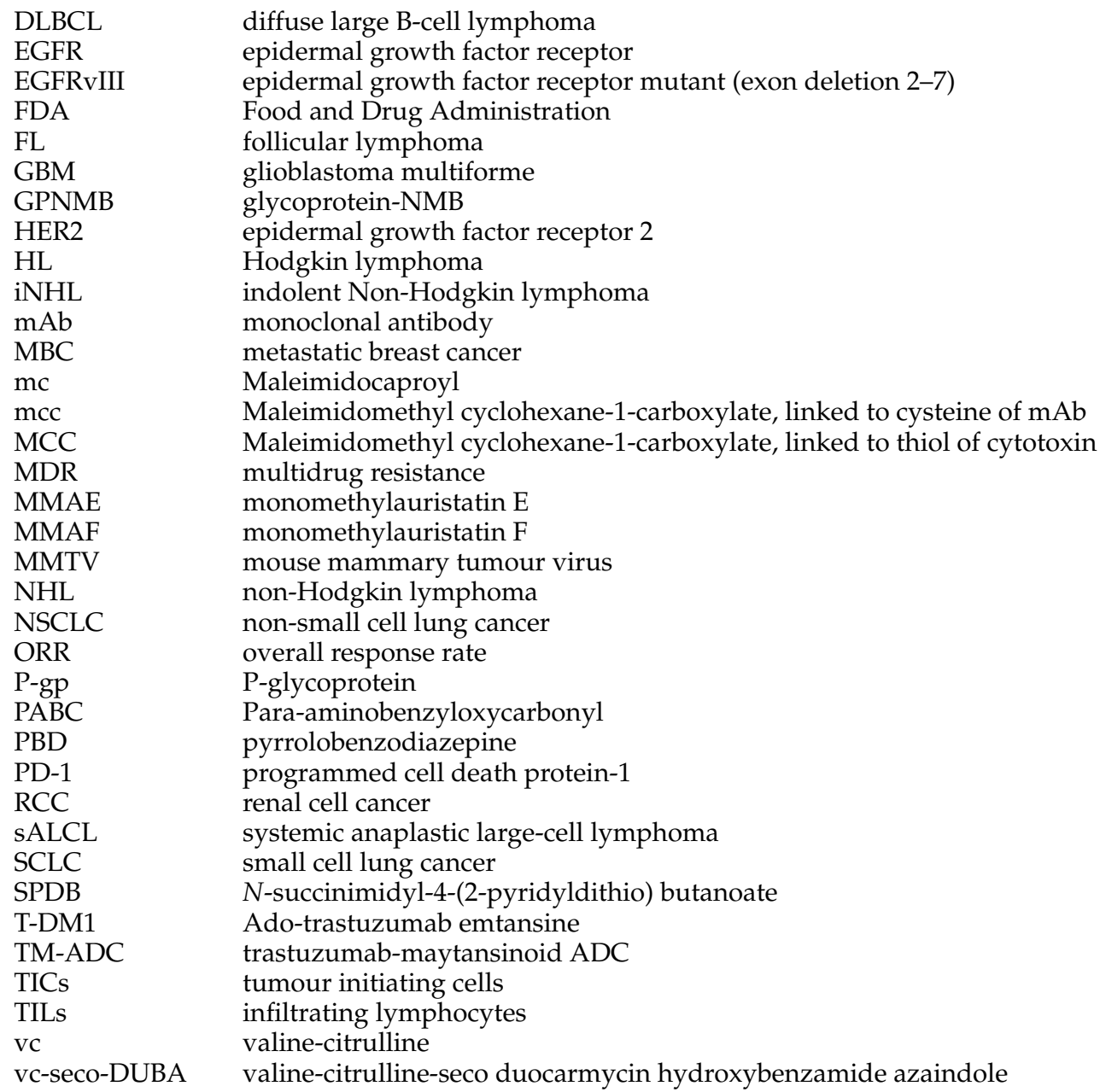

\section{References}

1. Schwartz, R.S. Paul Ehrlich's magic bullets. N. Engl. J. Med. 2004, 350, 1079-1080. [CrossRef] [PubMed]

2. Scott, A.M.; Wolchok, J.D.; Old, L.J. Antibody therapy of cancer. Nat. Rev. Cancer 2012, 12, 278-287. [CrossRef] [PubMed]

3. Shuptrine, C.W.; Surana, R.; Weiner, L.M. Monoclonal antibodies for the treatment of cancer. Semin. Cancer Biol. 2012, 22, 3-13. [CrossRef] [PubMed]

4. Kubota, T.; Niwa, R.; Satoh, M.; Akinaga, S.; Shitara, K.; Hanai, N. Engineered therapeutic antibodies with improved effector functions. Cancer Sci. 2009, 100, 1566-1572. [CrossRef] [PubMed]

5. Sievers, E.L.; Senter, P.D. Antibody-Drug Conjugates in Cancer Therapy. Annu. Rev. Med. 2013, 64, 15-29. [CrossRef] [PubMed]

6. Panowksi, S.; Bhakta, S.; Raab, H.; Polakis, P.; Junutula, J.R. Site-specific antibody drug conjugates for cancer therapy. $m A$ Abs 2014, 6, 34-45.

7. Jaracz, S.; Chen, J.; Kuznetsova, L.V.; Ojima, I. Recent advances in tumor-targeting anticancer drug conjugates. Bioorg. Med. Chem. 2005, 13, 5043-5054. [CrossRef] [PubMed]

8. Chari, R.V.J. Targeted Cancer Therapy: Conferring Specificity to Cytotoxic Drugs. Acc. Chem. Res. 2008, 41, 98-107. [CrossRef] [PubMed]

9. Shefet-Carasso, L.; Benhar, I. Antibody-targeted drugs and drug resistance-Challenges and solutions. Drug Resist. Updates 2015, 18, 36-46. [CrossRef] [PubMed]

10. Parakh, S.; Parslow, A.C.; Gan, H.K.; Scott, A.M. Antibody-mediated delivery of therapeutics for cancer therapy. Expert Opin. Drug Deliv. 2016, 13, 401-419. [CrossRef] [PubMed]

11. Teicher, B.A.; Chari, R.V.J. Antibody Conjugate Therapeutics: Challenges and Potential. Clin. Cancer Res. 2011, 17, 6389-6397. [CrossRef] [PubMed] 
12. Flygare, J.A.; Pillow, T.H.; Aristoff, P. Antibody-Drug Conjugates for the Treatment of Cancer. Chem. Biol. Drug Des. 2013, 81, 113-121. [CrossRef] [PubMed]

13. Senter, P.D. Potent antibody drug conjugates for cancer therapy. Curr. Opin. Chem. Biol. 2009, 13, $235-244$. [CrossRef] [PubMed]

14. Sochaj, A.M.; Świderska, K.W.; Otlewski, J. Current methods for the synthesis of homogeneous antibody-drug conjugates. Biotechnol. Adv. 2015, 33, 775-784. [CrossRef] [PubMed]

15. Krop, I.E.; Beeram, M.; Modi, S.; Jones, S.F.; Holden, S.N.; Yu, W.; Girish, S.; Tibbitts, J.; Yi, J.H.; Sliwkowski, M.X.; et al. Phase I Study of Trastuzumab-DM1, an HER2 Antibody-Drug Conjugate, Given Every 3 Weeks to Patients With HER2-Positive Metastatic Breast Cancer. J. Clin. Oncol. 2010, 28, 2698-2704. [CrossRef] [PubMed]

16. Hamblett, K.J. Effects of Drug Loading on the Antitumor Activity of a Monoclonal Antibody Drug Conjugate. Clin. Cancer Res. 2004, 10, 7063-7070. [CrossRef] [PubMed]

17. Chudasama, V.; Maruani, A.; Caddick, S. Recent advances in the construction of antibody-drug conjugates. Nat. Chem. 2016, 8, 114-119. [CrossRef] [PubMed]

18. Polson, A.G.; Calemine-Fenaux, J.; Chan, P.; Chang, W.; Christensen, E.; Clark, S.; de Sauvage, F.J.; Eaton, D.; Elkins, K.; Elliott, J.M.; et al. Antibody-Drug Conjugates for the Treatment of Non-Hodgkin's Lymphoma: Target and Linker-Drug Selection. Cancer Res. 2009, 69, 2358-2364. [CrossRef] [PubMed]

19. Senter, P.D.; Sievers, E.L. The discovery and development of brentuximab vedotin for use in relapsed Hodgkin lymphoma and systemic anaplastic large cell lymphoma. Nat. Biotechnol. 2012, 30, 631-637. [CrossRef] [PubMed]

20. Jain, N.; Smith, S.W.; Ghone, S.; Tomczuk, B. Current ADC Linker Chemistry. Pharm. Res. 2015, 32, 3526-3540. [CrossRef] [PubMed]

21. Hamann, P.R.; Hinman, L.M.; Hollander, I.; Beyer, C.F.; Lindh, D.; Holcomb, R.; Hallett, W.; Tsou, H.-R.; Upeslacis, J.; Shochat, D.; et al. Gemtuzumab ozogamicin, a potent and selective anti-CD33 antibody-calicheamicin conjugate for treatment of acute myeloid leukemia. Bioconjug. Chem. 2002, 13, 47-58. [CrossRef] [PubMed]

22. Kigawa, J.; Minagawa, Y.; Kanamori, Y.; Itamochi, H.; Cheng, X.; Okada, M.; Oishi, T.; Terakawa, N. Glutathione concentration may be a useful predictor of response to second-line chemotherapy in patients with ovarian cancer. Cancer 1998, 82, 697-702. [CrossRef]

23. Jones, D.P.; Carlson, J.L.; Mody, V.C.; Cai, J.; Lynn, M.J.; Sternberg, P. Redox state of glutathione in human plasma. Free Radic. Biol. Med. 2000, 28, 625-635. [CrossRef]

24. Saito, G.; Swanson, J.A.; Lee, K.-D. Drug delivery strategy utilizing conjugation via reversible disulfide linkages: role and site of cellular reducing activities. Adv. Drug Deliv. Rev. 2003, 55, 199-215. [CrossRef]

25. Tothill, R.; Estall, V.; Rischin, D. Merkel Cell Carcinoma: Emerging Biology, Current Approaches, and Future Directions. Am. Soc. Clin. Oncol. 2015, 35, 519-526. [CrossRef] [PubMed]

26. Doronina, S.O.; Mendelsohn, B.A.; Bovee, T.D.; Cerveny, C.G.; Alley, S.C.; Meyer, D.L.; Oflazoglu, E.; Toki, B.E.; Sanderson, R.J.; Zabinski, R.F.; et al. Enhanced activity of monomethylauristatin F through monoclonal antibody delivery: effects of linker technology on efficacy and toxicity. Bioconjug. Chem. 2006, 17, 114-124. [CrossRef] [PubMed]

27. LoRusso, P.M.; Weiss, D.; Guardino, E.; Girish, S.; Sliwkowski, M.X. Trastuzumab emtansine: A unique antibody-drug conjugate in development for human epidermal growth factor receptor 2-positive cancer. Clin. Cancer Res. 2011, 17, 6437-6447. [CrossRef] [PubMed]

28. Erickson, H.K. Antibody-Maytansinoid Conjugates Are Activated in Targeted Cancer Cells by Lysosomal Degradation and Linker-Dependent Intracellular Processing. Cancer Res. 2006, 66, 4426-4433. [CrossRef] [PubMed]

29. Girish, S.; Gupta, M.; Wang, B.; Lu, D.; Krop, I.E.; Vogel, C.L.; Burris, H.A., III; LoRusso, P.M.; Yi, J.-H.; Saad, O; et al. Clinical pharmacology of trastuzumab emtansine (T-DM1): an antibody-drug conjugate in development for the treatment of HER2-positive cancer. Cancer Chemother. Pharmacol. 2012, 69, 1229-1240. [CrossRef] [PubMed]

30. Dumontet, C.; Jordan, M.A. Microtubule-binding agents: A dynamic field of cancer therapeutics. Nat. Rev. Drug Discov. 2010, 9, 790-803. [CrossRef] [PubMed] 
31. Oroudjev, E.; Lopus, M.; Wilson, L.; Audette, C.; Provenzano, C.; Erickson, H.; Kovtun, Y.; Chari, R.; Jordan, M.A. Maytansinoid-antibody conjugates induce mitotic arrest by suppressing microtubule dynamic instability. Mol. Cancer Ther. 2010, 9, 2700-2713. [CrossRef] [PubMed]

32. Komlodi-Pasztor, E.; Sackett, D.; Wilkerson, J.; Fojo, T. Mitosis is not a key target of microtubule agents in patient tumors. Nat. Rev. Clin. Oncol. 2011, 8, 244-250. [CrossRef] [PubMed]

33. Poruchynsky, M.S.; Komlodi-Pasztor, E.; Trostel, S.; Wilkerson, J.; Regairaz, M.; Pommier, Y.; Zhang, X.; Kumar Maity, T.; Robey, R.; Burotto, M.; et al. Microtubule-targeting agents augment the toxicity of DNA-damaging agents by disrupting intracellular trafficking of DNA repair proteins. Proc. Natl. Acad. Sci. USA 2015, 112, 1571-1576. [CrossRef] [PubMed]

34. Hartley, J.A. The development of pyrrolobenzodiazepines as antitumour agents. Expert Opin. Investig. Drugs 2011, 20, 733-744. [CrossRef] [PubMed]

35. Sutherland, M.S.K.; Walter, R.B.; Jeffrey, S.C.; Burke, P.J.; Yu, C.; Kostner, H.; Stone, I.; Ryan, M.C.; Sussman, D.; Lyon, R.P. SGN-CD33A: A novel CD33-targeting antibody-drug conjugate using a pyrrolobenzodiazepine dimer is active in models of drug-resistant AML. Blood 2013, 122, 1455-1463. [CrossRef] [PubMed]

36. Elgersma, R.C.; Coumans, R.G.E.; Huijbregts, T.; Menge, W.M.P.B.; Joosten, J.A.F.; Spijker, H.J.; de Groot, F.M.H.; van der Lee, M.M.C.; Ubink, R.; van den Dobbelsteen, D.J.; et al. Design, Synthesis, and Evaluation of Linker-Duocarmycin Payloads: Toward Selection of HER2-Targeting Antibody-Drug Conjugate SYD985. Mol. Pharm. 2015, 12, 1813-1835. [CrossRef] [PubMed]

37. Van der Lee, M.M.C.; Groothuis, P.G.; Ubink, R.; van der Vleuten, M.A.J.; van Achterberg, T.A.; Loosveld, E.M.; Damming, D.; Jacobs, D.C.H.; Rouwette, M.; Egging, D.F.; et al. The Preclinical Profile of the Duocarmycin-Based HER2-Targeting ADC SYD985 Predicts for Clinical Benefit in Low HER2-Expressing Breast Cancers. Mol. Cancer Ther. 2015, 14, 692-703. [CrossRef] [PubMed]

38. Yu, S.-F.; Zheng, B.; Go, M.; Lau, J.; Spencer, S.; Raab, H.; Soriano, R.; Jhunjhunwala, S.; Cohen, R.; Caruso, M.; et al. A Novel Anti-CD22 Anthracycline-Based Antibody-Drug Conjugate (ADC) That Overcomes Resistance to Auristatin-Based ADCs. Clin. Cancer Res. 2015, 21, 3298-3306. [CrossRef] [PubMed]

39. Moldenhauer, G.; Salnikov, A.V.; Luttgau, S.; Herr, I.; Anderl, J.; Faulstich, H. Therapeutic Potential of Amanitin-Conjugated Anti-Epithelial Cell Adhesion Molecule Monoclonal Antibody Against Pancreatic Carcinoma. J. Natl. Cancer Inst. 2012, 104, 622-634. [CrossRef] [PubMed]

40. Sachdev, J.; Edelman, M.; Harb, W.; Matei, D.; Nguyen, B.; Burgess, S. P1.08. A phase 1 study of 3 different schedules of the folic acid-tubulysin small-molecule drug conjugate EC1456 in pts with advanced solid tumors. Ann. Oncol. 2015, 26. [CrossRef]

41. Sahin, U.; Hartmann, F.; Senter, P.; Pohl, C.; Engert, A.; Diehl, V.; Pfreundschuh, M. Specific activation of the prodrug mitomycin phosphate by a bispecific anti-CD30/anti-alkaline phosphatase monoclonal antibody. Cancer Res. 1990, 50, 6944-6948. [PubMed]

42. Deng, C.; Pan, B.; O'Connor, O.A. Brentuximab vedotin. Clin. Cancer Res. 2013, 19, 22-27. [CrossRef] [PubMed]

43. Fromm, J.R.; McEarchern, J.A.; Kennedy, D.; Thomas, A.; Shustov, A.R.; Gopal, A.K. Clinical binding properties, internalization kinetics, and clinicopathologic activity of brentuximab vedotin: An antibody-drug conjugate for CD30-positive lymphoid neoplasms. Clin. Lymphoma Myeloma Leuk. 2012, 12, 280-283. [CrossRef] [PubMed]

44. Junttila, M.R.; Mao, W.; Wang, X.; Wang, B.-E.; Pham, T.; Flygare, J.; Yu, S.-F.; Yee, S.; Goldenberg, D.; Fields, C.; et al. Targeting LGR5 ${ }^{+}$cells with an antibody-drug conjugate for the treatment of colon cancer. Sci. Transl. Med. 2015, 7. [CrossRef] [PubMed]

45. Bross, P.F.; Beitz, J.; Chen, G.; Chen, X.H.; Duffy, E.; Kieffer, L.; Roy, S.; Sridhara, R.; Rahman, A.; Williams, G.; et al. Approval summary: gemtuzumab ozogamicin in relapsed acute myeloid leukemia. Clin. Cancer Res. 2001, 7, 1490-1496. [PubMed]

46. Petersdorf, S.H.; Kopecky, K.J.; Slovak, M.; Willman, C.; Nevill, T.; Brandwein, J.; Larson, R.A.; Erba, H.P.; Stiff, P.J.; Stuart, R.K.; et al. A phase 3 study of gemtuzumab ozogamicin during induction and postconsolidation therapy in younger patients with acute myeloid leukemia. Blood 2013, 121, 4854-4860. [CrossRef] [PubMed]

47. Burnett, A.K.; Hills, R.K.; Milligan, D.; Kjeldsen, L.; Kell, J.; Russell, N.H.; Yin, J.A.L.; Hunter, A.; Goldstone, A.H.; Wheatley, K. Identification of Patients With Acute Myeloblastic Leukemia Who Benefit From the Addition of Gemtuzumab Ozogamicin: Results of the MRC AML15 Trial. J. Clin. Oncol. 2011, 29, 369-377. [CrossRef] [PubMed] 
48. Burnett, A.K.; Russell, N.H.; Hills, R.K.; Kell, J.; Freeman, S.; Kjeldsen, L.; Hunter, A.E.; Yin, J.; Craddock, C.F.; Dufva, I.H.; et al. Addition of Gemtuzumab Ozogamicin to Induction Chemotherapy Improves Survival in Older Patients With Acute Myeloid Leukemia. J. Clin. Oncol. 2012, 30, 3924-3931. [CrossRef] [PubMed]

49. Delaunay, J.; Recher, C.; Pigneux, A.; Witz, F.; Vey, N.; Blanchet, O.; Lefebvre, P.; Luquet, I.; Guillerme, I.; Volteau, C. Addition of gemtuzumab ozogamycin to chemotherapy improves event-free survival but not overall survival of AML patients with intermediate cytogenetics not eligible for allogeneic transplantation. Results of the GOELAMS AML 2006 IR study. Blood 2011, 118, 79.

50. Castaigne, S.; Pautas, C.; Terré, C.; Raffoux, E.; Bordessoule, D.; Bastie, J.-N.; Legrand, O.; Thomas, X.; Turlure, P.; Reman, O.; et al. Effect of gemtuzumab ozogamicin on survival of adult patients with de-novo acute myeloid leukaemia (ALFA-0701): A randomised, open-label, phase 3 study. Lancet 2012, 379, 1508-1516. [CrossRef]

51. Ravandi, F.; Estey, E.H.; Appelbaum, F.R.; Lo-Coco, F.; Schiffer, C.A.; Larson, R.A.; Burnett, A.K.; Kantarjian, H.M. Gemtuzumab Ozogamicin: Time to Resurrect? J. Clin. Oncol. 2012, 30, 3921-3923. [CrossRef] [PubMed]

52. Estey, E. Treatment of AML: Resurrection for gemtuzumab ozogamicin? Lancet 2012, 379, 1468-1469. [CrossRef]

53. Dang, N.H.; Ogura, M.; Castaigne, S.; Fayad, L.; Jerkeman, M.; Radford, J.A.; Pezzutto, A.; Bondarenko, I.; Stewart, D.A.; Shnaidman, M. Randomized, phase 3 trial of inotuzumab ozogamicin plus rituximab (R-InO) versus chemotherapy for relapsed/refractory aggressive B-cell non-Hodgkin lymphoma (B-NHL). J. Clin. Oncol. 2014, 32, 8529.

54. Younes, A.; Gopal, A.K.; Smith, S.E.; Ansell, S.M.; Rosenblatt, J.D.; Savage, K.J.; Ramchandren, R.; Bartlett, N.L.; Cheson, B.D.; de Vos, S.; et al. Results of a pivotal phase II study of brentuximab vedotin for patients with relapsed or refractory Hodgkin's lymphoma. J. Clin. Oncol. 2012, 30, 2183-2189. [CrossRef] [PubMed]

55. Berdeja, J.G.; Hernandez-Ilizaliturri, F.; Chanan-Khan, A.; Patel, M.; Kelly, K.R.; Running, K.L.; Murphy, M.; Guild, R.; Carrigan, C.; Ladd, S. Phase I study of lorvotuzumab mertansine (LM, IMGN901) in combination with lenalidomide (Len) and dexamethasone (Dex) in patients with CD56-positive relapsed or relapsed/refractory multiple myeloma (MM). Blood 2012, 120, 728.

56. Kelly, K.R.; Chanan-Khan, A.; Somlo, G.; Heffner, L.T. Indatuximab Ravtansine (BT062) in Combination with Lenalidomide and Low-Dose Dexamethasone in Patients with Relapsed and/or Refractory Multiple. Blood 2014, 124, 4736 .

57. Verma, S.; Miles, D.; Gianni, L.; Krop, I.E.; Welslau, M.; Baselga, J.; Pegram, M.; Oh, D.-Y.; Diéras, V.; Guardino, E.; et al. Trastuzumab Emtansine for HER2-Positive Advanced Breast Cancer. N. Engl. J. Med. 2012, 367, 1783-1791. [CrossRef] [PubMed]

58. Boni, V.; Rixe, O.; Rasco, D.; Gomez-Roca, C.; Calvo, E.; Morris, J.C.; Tolcher, A.W.; Assadourian, S.; Guillemin, H.; Delord, J.-P. Abstract A73: A Phase I first-in-human (FIH) study of SAR566658, an anti CA6-antibody drug conjugate (ADC), in patients (Pts) with CA6-positive advanced solid tumors (STs) (NCT01156870). Mol. Cancer Ther. 2013, 12. [CrossRef]

59. Morschhauser, F.; Flinn, I. Preliminary results of a phase II randomized study (ROMULUS) of polatuzumab vedotin (PoV) or pinatuzumab vedotin (PiV) plus rituximab (RTX) in patients (Pts) with relapsed/refractory $(\mathrm{R} / \mathrm{R})$ non-Hodgkin lymphoma (NHL). In Proceedings of the 50th Annual Meeting of American Society Of Clinical Oncology, Chicago, IL, USA, 30 May-3 June 2014.

60. Ott, P.A.; Hamid, O.; Pavlick, A.C.; Kluger, H.; Kim, K.B.; Boasberg, P.D.; Simantov, R.; Crowley, E.; Green, J.A.; Hawthorne, T.; et al. Phase I/II Study of the Antibody-Drug Conjugate Glembatumumab Vedotin in Patients With Advanced Melanoma. J. Clin. Oncol. 2014, 32, 3659-3666. [CrossRef] [PubMed]

61. Petrylak, D.P.; Smith, D.C.; Appleman, L.J.; Fleming, M.T.; Hussain, A.; Dreicer, R.; Sartor, A.O.; Shore, N.D.; Vogelzang, N.J.; Youssoufian, H. A phase 2 trial of prostate-specific membrane antigen antibody drug conjugate (PSMA ADC) in taxane-refractory metastatic castration-resistant prostate cancer (mCRPC). Blood 2014, 32, 5023.

62. Gan, H.K.; Papadopoulos, K.P.; Fichtel, L.; Lassman, A.B.; Merrell, R.; Van Den Bent, M.J.; Kumthekar, P.; Scott, A.M.; Pedersen, M.; Gomez, E.J.; et al. Phase I study of ABT-414 mono- or combination therapy with temozolomide (TMZ) in recurrent glioblastoma (GBM). In Proceedings of the ASCO Annual Meeting, Chicago, IL, USA, 29 May-2 June 2015. 
63. Starodub, A.; Ocean, A.J.; Messersmith, W.A.; Picozzi, V.J.; Guarino, M.J.; Thomas, S.S.; Bardia, A.; Shah, M.A.; Govindan, S.V.; Maliakal, P.P. Phase I/II trial of IMMU-132 (isactuzumab govitecan), an anti-Trop-2-SN-38 antibody drug conjugate (ADC): Results in patients with metastatic gastrointestinal (GI) cancers. Blood 2015, 33, 703-747.

64. De Claro, R.A.; McGinn, K.; Kwitkowski, V.; Bullock, J.; Khandelwal, A.; Habtemariam, B.; Ouyang, Y.; Saber, H.; Lee, K.; Koti, K.; et al. U.S. Food and Drug Administration Approval Summary: Brentuximab Vedotin for the Treatment of Relapsed Hodgkin Lymphoma or Relapsed Systemic Anaplastic Large-Cell Lymphoma. Clin. Cancer Res. 2012, 18, 5845-5849. [CrossRef] [PubMed]

65. Moskowitz, C.H.; Nademanee, A.; Masszi, T.; Agura, E.; Holowiecki, J.; Abidi, M.H.; Chen, A.I.; Stiff, P.; Gianni, A.M.; Carella, A. Brentuximab vedotin as consolidation therapy after autologous stem-cell transplantation in patients with Hodgkin's lymphoma at risk of relapse or progression (AETHERA): A randomised, double-blind, placebo-controlled, phase 3 trial. Lancet 2015, 385, 1853-1862. [CrossRef]

66. Amiri-Kordestani, L.; Blumenthal, G.M.; Xu, Q.C.; Zhang, L.; Tang, S.W.; Ha, L.; Weinberg, W.C.; Chi, B.; Candau-Chacon, R.; Hughes, P.; et al. FDA approval: ado-trastuzumab emtansine for the treatment of patients with HER2-positive metastatic breast cancer. Clin. Cancer Res. 2014, 20, 4436-4441. [CrossRef] [PubMed]

67. Lewis Phillips, G.D.; Li, G.; Dugger, D.L.; Crocker, L.M.; Parsons, K.L.; Mai, E.; Blattler, W.A.; Lambert, J.M.; Chari, R.V.J.; Lutz, R.J.; et al. Targeting HER2-Positive Breast Cancer with Trastuzumab-DM1, an Antibody-Cytotoxic Drug Conjugate. Cancer Res. 2008, 68, 9280-9290. [CrossRef] [PubMed]

68. Barok, M.; Tanner, M.; Koninki, K.; Isola, J. Trastuzumab-DM1 causes tumour growth inhibition by mitotic catastrophe in trastuzumab-resistant breast cancer cells in vivo. Breast Cancer Res. 2011, 13, R46. [CrossRef] [PubMed]

69. Hurvitz, S.A.; Dirix, L.; Kocsis, J.; Bianchi, G.V.; Lu, J.; Vinholes, J.; Guardino, E.; Song, C.; Tong, B.; $\mathrm{Ng}$, V.; et al. Phase II Randomized Study of Trastuzumab Emtansine Versus Trastuzumab Plus Docetaxel in Patients With Human Epidermal Growth Factor Receptor 2-Positive Metastatic Breast Cancer. J. Clin. Oncol. 2013, 31, 1157-1163. [CrossRef] [PubMed]

70. Dieras, V.; Harbeck, N.; Albain, K.; Burris, H.; Awada, A.; Crivellari, D.; Andre, F.; Choi, Y. J.; Huang, J.; Miller, K.D. Abstract P3-14-01: A phase Ib/II trial of trastuzumab-DM1 with pertuzumab for patients with HER2-positive, locally advanced or metastatic breast cancer: interim efficacy and safety results. Cancer Res. 2010, 70. [CrossRef]

71. Burris, H.A.; Rugo, H.S.; Vukelja, S.J.; Vogel, C.L.; Borson, R.A.; Limentani, S.; Tan-Chiu, E.; Krop, I.E.; Michaelson, R.A.; Girish, S.; et al. Phase II study of the antibody drug conjugate trastuzumab-DM1 for the treatment of human epidermal growth factor receptor 2 (HER2)-positive breast cancer after prior HER2-directed therapy. J. Clin. Oncol. 2011, 29, 398-405. [CrossRef] [PubMed]

72. Hughes, B. Antibody-drug conjugates for cancer: poised to deliver? Nat. Rev. Drug Discov. 2010, 9, 665-667. [CrossRef] [PubMed]

73. Krop, I.E.; LoRusso, P.; Miller, K.D.; Modi, S.; Yardley, D.; Rodriguez, G.; Guardino, E.; Lu, M.; Zheng, M.; Girish, S.; et al. A phase II study of trastuzumab emtansine in patients with human epidermal growth factor receptor 2-positive metastatic breast cancer who were previously treated with trastuzumab, lapatinib, an anthracycline, a taxane, and capecitabine. J. Clin. Oncol. 2012, 30, 3234-3241. [CrossRef] [PubMed]

74. De Goeij, B.E.; Lambert, J.M. New developments for antibody-drug conjugate-based therapeutic approaches. Curr. Opin. Immunol. 2016, 40, 14-23. [CrossRef] [PubMed]

75. Younes, A.; Kim, S.; Romaguera, J.; Copeland, A.; Farial, S.D.C.; Kwak, L.W.; Fayad, L.; Hagemeister, F.; Fanale, M.; Neelapu, S.; et al. Phase I Multidose-Escalation Study of the Anti-CD19 Maytansinoid Immunoconjugate SAR3419 Administered by Intravenous Infusion Every 3 Weeks to Patients with Relapsed/Refractory B-Cell Lymphoma. J. Clin. Oncol. 2012, 30, 2776-2782. [CrossRef] [PubMed]

76. Thompson, J.A.; Motzer, R. Phase I studies of anti-ENPP3 antibody drug conjugates (ADCs) in advanced refractory renal cell carcinomas (RRCC). In Proceedings of the ASCO Annual Meeting, Chicago, IL, USA, 29 May-2 June 2015.

77. Goff, L.W.; Papadopoulos, K.; Posey, J.A.; Phan, A.T.; Patnaik, A.; Miller, J.G.; Zildjian, S.; O’Leary, J.J.; Qin, A.; Tolcher, A. A phase II study of IMGN242 (huC242-DM4) in patients with CanAg-positive gastric or gastroesophageal (GE) junction cancer. In Proceedings of the 45th ASCO Annual Meeting, Orlando, IL, USA, 29 May-2 June 2009 
78. Bendell, J.; Blumenschein, G.; Zinner, R.; Hong, D.; Jones, S.; Infante, J.; Burris, H.; Rajagopalan, P.; Kornacker, M.; Henderson, D.; et al. Abstract LB-291: First-in-human phase I dose escalation study of a novel anti-mesothelin antibody drug conjugate (ADC), BAY 94-9343, in patients with advanced solid tumors. Cancer Res. 2014, 73. [CrossRef]

79. Moore, K.; Ponte, J.; LoRusso, P.; Birrer, M.; Bauer, T.M.; Borghei, H.; O’Malley, D.; Ruiz-Soto, R.; Lutz, R.J.; Malik, L. Relationship of pharmacokinetics (PK), toxicity and initial evidence of clinical activity with IMGN853, a folate receptor alpha (FR $\alpha$ )-targeting antibody drug conjugate in patients with epithelial ovarian cancer and other FR $\alpha$-positive solid tumors. J. Clin. Oncol. 2014, 32, 5571.

80. Oak, E.; Bartlett, N.L. A safety evaluation of brentuximab vedotin for the treatment of Hodgkin lymphoma. Expert Opin. Drug Saf. 2016, 15, 875-882. [CrossRef] [PubMed]

81. Goy, A.; Forero, A.; Wagner-Johnston, N.; Christopher Ehmann, W.; Tsai, M.; Hatake, K.; Ananthakrishnan, R.; Volkert, A.; Vandendries, E.; Ogura, M. A phase 2 study of inotuzumab ozogamicin in patients with indolent B-cell non-Hodgkin lymphoma refractory to rituximab alone, rituximab and chemotherapy, or radioimmunotherapy. Br. J. Haematol. 2016. [CrossRef] [PubMed]

82. Onitilo, A.A.; Engel, J.M.; Stankowski, R.V. Cardiovascular toxicity associated with adjuvant trastuzumab therapy: Prevalence, patient characteristics, and risk factors. Ther. Adv. Drug Saf. 2014, 5, 154-166. [CrossRef] [PubMed]

83. Uppal, H.; Doudement, E.; Mahapatra, K.; Darbonne, W.C.; Bumbaca, D.; Shen, B.-Q.; Du, X.; Saad, O.; Bowles, K.; Olsen, S.; et al. Potential mechanisms for thrombocytopenia development with trastuzumab emtansine (T-DM1). Clin. Cancer Res. 2015, 21, 123-133. [CrossRef] [PubMed]

84. Dosio, F.; Brusa, P.; Cattel, L. Immunotoxins and Anticancer Drug Conjugate Assemblies: The Role of the Linkage between Components. Toxins 2011, 3, 848-883. [CrossRef] [PubMed]

85. Bracci, L.; Schiavoni, G.; Sistigu, A.; Belardelli, F. Immune-based mechanisms of cytotoxic chemotherapy: implications for the design of novel and rationale-based combined treatments against cancer. Cell Death Differ. 2014, 21, 15-25. [CrossRef] [PubMed]

86. Müller, P.; Martin, K.; Theurich, S.; Schreiner, J.; Savic, S.; Terszowski, G.; Lardinois, D.; Heinzelmann-Schwarz, V.A.; Schlaak, M.; Kvasnicka, H.-M.; et al. Microtubule-depolymerizing agents used in antibody-drug conjugates induce antitumor immunity by stimulation of dendritic cells. Cancer Immunol. Res. 2014, 2, 741-755. [CrossRef] [PubMed]

87. Müller, P.; Kreuzaler, M.; Khan, T.; Thommen, D.S.; Martin, K.; Glatz, K.; Savic, S.; Harbeck, N.; Nitz, U.; Gluz, O.; et al. Trastuzumab emtansine (T-DM1) renders HER2+ breast cancer highly susceptible to CTLA-4/PD-1 blockade. Sci. Transl. Med. 2015, 7. [CrossRef] [PubMed]

88. Barok, M.; Joensuu, H.; Isola, J. Trastuzumab emtansine: mechanisms of action and drug resistance. Breast Cancer Res. 2014, 16, 1. [CrossRef] [PubMed]

89. Ritchie, M.; Tchistiakova, L.; Scott, N. Implications of receptor-mediated endocytosis and intracellular trafficking dynamics in the development of antibody drug conjugates. mAbs 2014, 5, 13-21. [CrossRef] [PubMed]

90. Loganzo, F.; Tan, X.; Sung, M.; Jin, G.; Myers, J.S.; Melamud, E.; Wang, F.; Diesl, V.; Follettie, M.T.; Musto, S.; et al. Tumor cells chronically treated with a trastuzumab-maytansinoid antibody-drug conjugate develop varied resistance mechanisms but respond to alternate treatments. Mol. Cancer Ther. 2015, 14, 952-963. [CrossRef] [PubMed]

91. Helman, E.; Wick, M.J.; Clark, M.J.; Gamez, L.; Boyle, S.; Papadopoulos, K.P.; Luo, S.; Tolcher, A.W.; Sripakdeevong, P.; Karbelashvili, M.; et al. Abstract 1457: Genomic characterization of a PDX model of T-DM1-resistant HER2+ invasive ductal carcinoma using augmented exome sequencing. Cancer Res. 2015, 75, 1457. [CrossRef]

92. O’Brien, C.; Cavet, G.; Pandita, A.; Hu, X.; Haydu, L.; Mohan, S.; Toy, K.; Rivers, C.S.; Modrusan, Z.; Amler, L.C.; et al. Functional genomics identifies ABCC3 as a mediator of taxane resistance in HER2-amplified breast cancer. Cancer Res. 2008, 68, 5380-5389. [CrossRef] [PubMed]

93. Szakács, G.; Paterson, J.K.; Ludwig, J.A.; Booth-Genthe, C.; Gottesman, M.M. Targeting multidrug resistance in cancer. Nat. Rev. Drug Discov. 2006, 5, 219-234. [CrossRef] [PubMed]

94. Gottesman, M.M. Mechanisms of Cancer Drug Resistance. Annu. Rev. Med. 2002, 53, 615-627. [CrossRef] [PubMed] 
95. Sammet, B.; Steinkühler, C.; Sewald, N. Antibody-drug conjugates in tumor therapy. Pharm. Pat. Anal. 2012, 1, 65-73. [CrossRef] [PubMed]

96. Loo, T.W.; Clarke, D.M. Recent progress in understanding the mechanism of P-glycoprotein-mediated drug efflux. J. Membr. Boil. 2005, 206, 173-185. [CrossRef] [PubMed]

97. Kovtun, Y.V.; Audette, C.A.; Mayo, M.F.; Jones, G.E.; Doherty, H.; Maloney, E.K.; Erickson, H.K.; Sun, X.; Wilhelm, S.; Ab, O.; et al. Antibody-Maytansinoid Conjugates Designed to Bypass Multidrug Resistance. Cancer Res. 2010, 70, 2528-2537. [CrossRef] [PubMed]

98. Chen, R.; Hou, J.; Newman, E.; Kim, Y.; Donohue, C.; Liu, X.; Thomas, S.H.; Forman, S.J.; Kane, S.E. CD30 Downregulation, MMAE Resistance, and MDR1 Upregulation Are All Associated with Resistance to Brentuximab Vedotin. Mol. Cancer Ther. 2015, 14, 1376-1384. [CrossRef] [PubMed]

(C) 2016 by the authors; licensee MDPI, Basel, Switzerland. This article is an open access article distributed under the terms and conditions of the Creative Commons Attribution (CC-BY) license (http://creativecommons.org/licenses/by/4.0/). 